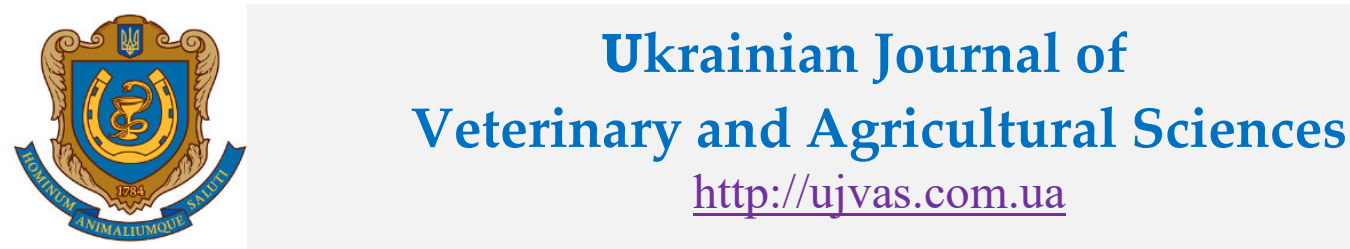

Stepan Gzhytskyi National University of Veterinary Medicine and Biotechnologies Lviv \begin{tabular}{l|l|ll} 
original article & UDC 619:612.129:636.085.8:636.4 & doi: 10.32718/ujvas2-2.06 & Number 2
\end{tabular}

\title{
Biochemical indices of piglets blood under the action of feed additive "Butaselmevit-plus"
}

\author{
T. V. Martyshuk ${ }^{1,2}$, B. V. Gutyj ${ }^{2}$, O. I. Vishchur ${ }^{1}$, V. B. Todoriuk ${ }^{2}$ \\ ${ }^{1}$ Institute of Animal Biology NAAS, Vasyl Stus Str., 38, Lviv, 79034, Ukraine \\ ${ }^{2}$ Stepan Gzhytskyi National University of Veterinary Medicine and Biotechnologies Lviv, Pekarska Str., 50, Lviv, 79010, \\ Ukraine
}

\begin{tabular}{|c|}
\hline $\begin{array}{l}\text { Article info } \\
\text { Received } 23.09 .2019 \\
\text { Received in revised form } \\
\quad 23.10 .2019 \\
\text { Accepted } 24.10 .2019\end{array}$ \\
\hline $\begin{array}{l}\text { Correspondence author } \\
\text { Bogdan Gutyj } \\
\text { Tel.: +38-068-136-20-54 } \\
\text { E-mail: bvh@ukr.net }\end{array}$ \\
\hline $\begin{array}{l}\text { (C) } 2019 \text { Martyshuk T. V. et al. This } \\
\text { is an open-access article distributed } \\
\text { under the terms of the Creative } \\
\text { Commons Attribution License, } \\
\text { which permits unrestricted use, } \\
\text { distribution, and reproduction in any } \\
\text { medium, provided the original } \\
\text { author and source are credited. }\end{array}$ \\
\hline$(\mathrm{cc}) \mathrm{BY}$ \\
\hline 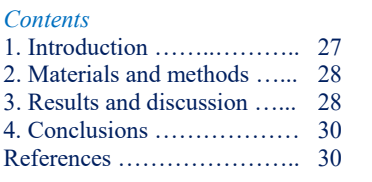 \\
\hline
\end{tabular}

\begin{abstract}
The purpose of the search was to investigate the influence of feed additive "Butaselmevit-plus" on the biochemical indices of piglets blood when weaned. The experiments were conducted on the basis of Ltd. "KOSHET" of Mukachevo district, Transcarpathian region. Two groups of pigs were formed - control (C) and experimental (E), in the number of 10 individuals in each group, selected on the basis of analogues - age, breed and body weight. In the suckling period, pigletss were kept under sows in special machines, had constant access to the mother, and from 5 days of age - free access to concentrated feed. The research material was blood collected in the morning by puncture of the cranial vena cava on the $20^{\text {th }}$ day of life (period before weaning), on the $25^{\text {th }}$ day of life (period before weaning), on the $30^{\text {th }}$ day of life ( 2 days after weaning), for 35 days of life ( 7 days after weaning), for 40 days of life (12 days after weaning). Weaning of piglets from sows at 28 days of age leads to a slight decrease in total protein and increased activity of aminotransferases. Increased activity of ALAT and ASAT in pigs' serum after weaning from sows reflects the nonspecific response of the organism to the action of stress factors and indicates an increased release of enzymes into the extracellular space. Feeding of piglets with feed additives "Butaselmevitplus" promotes to enhance the protein synthesizing function of the liver and reduce the activity of aminotransferases. The decrease in the activity of aminotransferases in the blood of piglets of the experimental group, indicates that the components of the feed additive counteract the influence of stress, and also contribute to the maintenance the integrity of cell membranes specific to these organ enzymes, which prevents their output from the cells.
\end{abstract}

Key words: piglets, oxidative stress, "Butaselmevit-plus" feed additive, blood, enzymes, proteins.

\section{Citation:}

Martyshuk, T. V., Gutyj, B. V., Vishchur, O. I., \& Todoriuk, V. B. (2019). Biochemical indices of piglets blood under the action of feed additive "Butaselmevit-plus". Ukrainian Journal of Veterinary and Agricultural Sciences, 2(2), 27-30.

\section{Introduction}

Homeostasis of the animal's internal environment depends first and foremost on the interconnection of the individual units of the metabolic processes and the lability of the components, that participate in the common system (Ahmad et al., 2011; Petrukh et al., 2015). Blood as one of the body's biological fluids responds quantitatively and qualitatively to changes in its composition to any exogenous or endogenous influences, and therefore, it is a kind of biomarker that allows to determine the general state of organs and systems and to evaluate the course of major metabolic processes (Martyshuk et al., 2016; Lavryshyn et al., 2016; Chala \& Rusak, 2016). That is why the search of biochemical indices of blood is one of the informative methods that allows to establish the transition of the physiological state of the organism to pathological.
New preparations and feed additives based on vegetable raw materials have been widely used in recent years to enhance the animal body's protective systems in the development of oxidative stress (Cherkashina \& Petrenko, 2006; Skry`pny'k, 2007; Saba et al., 2010; Zhukova et al., 2016; Gutyj et al., 2017). For the prevention of immunodeficiency in animals caused by the negative influence of exogenous environmental factors, more promising phytopreparations: echinacea, lemongrass fruits, ginseng root. According to the research of recent years, the most promising immunostimulants are considered to be the fruits of milk thistle (Khariv et al., 2016; Khariv et al., 2017; Gutyj et al., 2019). Among the biologically active additives, the most common are selenium preparations. Of particular importance is now the search of the interaction of selenium with other trace elements, which are normalized in the rations, due to the increased techno- 
genic influence on the animal organism (Sobolev et al., 2017).

The intensive development of animal husbandry at the present stage requires new approaches to the organization of feeding of farm animals and the introduction of modern feed additives, which are not commonly used in their pure form as feed, and are deliberately added to feed or water to improve their quality, productivity and animal welfare (Kotsumbas \& Hryniv, 2016).

The purpose of our research was to investigate the influence of feed additive "Butaselmevit-plus" on the biochemical indices of blood of piglets when weaned.

\section{Materials and methods}

The experiments were performed on the basis of LLC "KOSHET" Mukachevo district, Transcarpathian region. Two groups of pigs were formed - control (C) and experimental $(E)$, in the number of 10 individuals in each group, selected on the basis of analogues - age, breed and body weight. In the suckling period, pigs were kept under sows in special machines, had constant access to the mother, and from 5 days of age - free access to concentrated feed. Feeding of animals was carried out according to the norms for this age of pigs. Clinical and physiological examinations of piglets were conducted prior to the search. They took into account their general state and activity when eating feed. On the 28th day of life, piglets were weaned from the sow and regrouped from different nests for further retention and rearing, with changing dietary structure, which served as technological stress for the animal organism. Beginning at the age of 5 days, piglets of all groups were fed pre-stern compound feed. The piglets of the experimental group, from 21 to 40 days of age, were additionally fed the feed additive "Butaselmevit-plus" at a dose of $100 \mathrm{mg} / \mathrm{kg}$ of body weight per day.

The research material was blood collected in the morning prior to animals feeding by puncture of the cranial vena cava on $20^{\text {th }}$ day of life (period before weaning), on 25th day of life (period before weaning), for 30 days of life ( $2^{\text {nd }}$ day after weaning), on $35^{\text {th }}$ day of life (7 days after weaning), on $40^{\text {th }}$ day of life ( $2^{\text {nd }}$ day after weaning).

Protein-sensitizing liver function was determined by serum levels of total protein (biuret reaction) and protein fractions (by polyacrylamide gel electrophoresis). The activity of aspartate- (ASAT-K.F.2.6.1.1) and alanine- (ALATK.F.2.6.1.2) aminotransferases in serum was determined by the method of Reitman-Frenkel using the standard set of reagents NPF "Simko Ltd” (Vlizlo et al., 2012).

Analysis of the research results was performed using the Statistica 6.0 software package. Probability differences was evaluated by Student's t-criterion. The results were considered reliable at $\mathrm{P} \leq 0.05$.

\section{Results and discussion}

It is known that blood Indexes of piglets depend on many factors (physiological state, ration, productivity, etc.). We have investigated the basic indicators of blood, which reflect the state of metabolic processes in the organism of animals.

The results of the search showed that the content of total protein in the serum of 20 daily piglets of the control and experimental groups ranged from $52.84 \pm 1.20$ -
$52.75 \pm 1.22 \mathrm{~g} / \mathrm{l}$. On the $25^{\text {th }}$ day of the experiment, the level of total protein in the control and experimental groups increased by $14.6 \%$ and $15.8 \%$, respectively, compared to the previous day of searches (Table 1).

Table 1

Content of total protein in the serum of piglets blood by the action of feed additive "Butaselmevit-plus", g/l $(\mathrm{M} \pm \mathrm{m}$, $\mathrm{n}=5$ )

\begin{tabular}{ccc}
\hline The day of & \multicolumn{2}{c}{ Groups of piglets } \\
\cline { 2 - 3 } life & control & experimental \\
\hline $20^{\text {th }}$ day & $52.84 \pm 1.20$ & $52.75 \pm 1.22$ \\
$25^{\text {th }}$ day & $60.58 \pm 1.17$ & $61.08 \pm 0.87$ \\
$30^{\text {th }}$ day & $58.31 \pm 1.75$ & $61.54 \pm 1.10$ \\
$35^{\text {th }}$ day & $58.12 \pm 1.33$ & $61.78 \pm 0.91^{*}$ \\
$40^{\text {th }}$ day & $59.03 \pm 1.14$ & $61.24 \pm 0.95$ \\
\hline
\end{tabular}

Notes: the degree of probability compared to the control group data: $*-\mathrm{P}<0.05 ; * *-\mathrm{P}<0.01 ; * * *-\mathrm{P}<0.001$

After weaning in the blood of the piglets of the control group, the level of total protein at the $30^{\text {th }}$ and $35^{\text {th }}$ day of life fluctuated within $58.31 \pm 1.75$ and $58.12 \pm 1.33 \mathrm{~g} / \mathrm{l}$. The level of total protein was slightly higher in the blood of the experimental group during the indicated search period, which increased by $5.5 \%$ and $6.6 \%$, respectively, relative to the control group of animals.

Increase in total protein content in piglets serum from the experimental group during the specified periods of the experiment, compared with controls, indicates the stimulating influence of vitamins $A, D_{3}, E$ and milk thistle spotted in the content of feed additive on protein synthesis.

In the blood of the piglets of the control and experimental group after weaning on the $30^{\text {th }}, 35^{\text {th }}$ and $40^{\text {th }}$ days of the experiment, a higher content of albumins and a lower content of globulins were recorded (Tables 2 and 3). Thus, on the $30^{\text {th }}$ day of life piglets the level of albumin in the blood of the control group was increased by $5.55 \%$ and in the experimental group - by $4.86 \%$ relative to the indicators taken from the 25 daily pigs. The 35 -day-old piglets of the experimental group had an albumin level of $1.13 \%$ higher than the control group. At the $40^{\text {th }}$ day of the experiment, the level of albumin was the highest in the blood of the piglets of the control group.

Table 2

The level of albumin in the serum of piglets by the action of the feed additive "Butaselmevit-plus", \% $(M \pm m, n=5)$

\begin{tabular}{ccc}
\hline The day of & \multicolumn{2}{c}{ Groups of piglets } \\
\cline { 2 - 3 } life & control & experimental \\
\hline $20^{\text {th }}$ day & $33.62 \pm 0.97$ & $33.65 \pm 1.05$ \\
$25^{\text {th }}$ day & $33.69 \pm 1,00$ & $33.70 \pm 1.10$ \\
$30^{\text {th }}$ day & $39.24 \pm 1.85$ & $38.56 \pm 1.12$ \\
$35^{\text {th }}$ day & $38.39 \pm 1.56$ & $39.52 \pm 1.85$ \\
$40^{\text {th }}$ day & $42.64 \pm 1.97$ & $35.87 \pm 1.10^{* *}$ \\
\hline
\end{tabular}

Notes: the degree of probability compared to the control group data: $*-\mathrm{P}<0.05 ; * *-\mathrm{P}<0.01 ; * * *-\mathrm{P}<0.001$

The level of globulins in the blood of 25 daily pigs of the control and experimental groups ranged from $66.31 \pm 1.00$ and $66.30 \pm 1.10 \%$. After weaning of piglets from the experimental groups, the globulin level was decreased by the $30^{\text {th }}$ day of life, so in the blood of piglets in the control 
group the level of globulins was decreased by $5.55 \%$, and in the experimental group - by $4.86 \%$ relative to the indicators taken on the $25^{\text {th }}$ day of the experiment.

Table 3

The level of globulins in the serum of piglets by the action of the feed additive "Butaselmevit-plus", \% $(\mathrm{M} \pm \mathrm{m}, \mathrm{n}=5)$

\begin{tabular}{ccc}
\hline The day & \multicolumn{2}{c}{ Groups of piglets } \\
\cline { 2 - 3 } of life & control & experimental \\
\hline $20^{\text {th }}$ day & $66.38 \pm 0.97$ & $66.35 \pm 1.05$ \\
$25^{\text {th }}$ day & $66.31 \pm 1.00$ & $66.30 \pm 1.10$ \\
$30^{\text {th }}$ day & $60.76 \pm 1.85$ & $61.44 \pm 1.12$ \\
$35^{\text {th }}$ day & $61.61 \pm 1.56$ & $60.48 \pm 1.85$ \\
$40^{\text {th }}$ day & $57.36 \pm 1.97$ & $64.13 \pm 1.10^{* *}$ \\
\hline
\end{tabular}

Notes: the degree of probability compared to the control group data: $*-\mathrm{P}<0.05 ; * *-\mathrm{P}<0.01 ; * * *-\mathrm{P}<0.001$

It is important to determine the functional status of piglets' liver before and after weaning. The functional state of the liver was examined for the activity of aminotransferases, namely: the activity of alanine and aspartate aminotransferases. It was found that the activity of alanine aminotransferase in the blood of piglets before weaning ranged from $0.15-0.17 \mathrm{mkat} / \mathrm{l}$. After weaning, we observed an increase in the activity of the investigated enzyme in the piglets blood of the control group by $11.8 \%$. In the future, the activity of ALAT in the serum of piglets of the control group was increased to $0.21 \pm 0.010 \mathrm{mkat} / 1$. In the serum of piglets of the experimental group, the activity of this enzyme in the 30day-old piglets was decreased by $21 \%$, whereas in the 35 day-old pigs, respectively, by $33 \%$ relatively to the indicators of the control group (Table 4).

\section{Table 4}

The activity of alanine aminotransferase in serum of piglets under the action of feed additive "Butaselmevit-plus", $\mathrm{mkat} / \mathrm{l}(\mathrm{M} \pm \mathrm{m}, \mathrm{n}=5)$

\begin{tabular}{ccc}
\hline The day & \multicolumn{2}{c}{ Groups of piglets } \\
\cline { 2 - 3 } of life & control & experimental \\
\hline $20^{\text {th }}$ day & $0.16 \pm 0.008$ & $0.15 \pm 0.008$ \\
$25^{\text {th }}$ day & $0.17 \pm 0.008$ & $0.16 \pm 0.009$ \\
$30^{\text {th }}$ day & $0.19 \pm 0.014$ & $0.15 \pm 0.016^{*}$ \\
$35^{\text {th }}$ day & $0.21 \pm 0.009$ & $0.14 \pm 0.015^{* *}$ \\
$40^{\text {th }}$ day & $0.21 \pm 0.010$ & $0.15 \pm 0.014^{* *}$ \\
\hline
\end{tabular}

Notes: the degree of probability compared to the control group data: $*-\mathrm{P}<0.05 ; * *-\mathrm{P}<0.01 ; * * *-\mathrm{P}<0.001$

\section{Table 5}

The activity of aspartate-aminotransferase in serum of piglets under the action of feed additive "Butaselmevit-plus", $\mathrm{mkat} / \mathrm{l}(\mathrm{M} \pm \mathrm{m}, \mathrm{n}=5)$

\begin{tabular}{ccc}
\hline The day of & \multicolumn{2}{c}{ Groups of piglets } \\
\cline { 2 - 3 } life & control & experimental \\
\hline $20^{\text {th }}$ day & $0.19 \pm 0.010$ & $0.18 \pm 0.010$ \\
$25^{\text {th }}$ day & $0.19 \pm 0.011$ & $0.19 \pm 0.009$ \\
$30^{\text {th }}$ day & $0.22 \pm 0.010$ & $0.17 \pm 0.012^{* *}$ \\
$35^{\text {th }}$ day & $0.24 \pm 0.017$ & $0.18 \pm 0.008^{* *}$ \\
$40^{\text {th }}$ day & $0.23 \pm 0.015$ & $0.18 \pm 0.015^{*}$ \\
\hline
\end{tabular}

Notes: the degree of probability compared to the control group data: $*-\mathrm{P}<0.05 ; * *-\mathrm{P}<0.01 ; * * *-\mathrm{P}<0.001$
Similar changes were found in the search of the activity of aspartate aminotransferase, which in the control group of piglets after weaning at 30 days of age increased by $15.8 \%$ compared to the previous day of research. The highest activity of the enzyme was in 35 daily piglets of the control group, where, respectively, it was $0.24 \pm 0.017 \mathrm{mkat} / \mathrm{l}$ (Table 5).

The serum of the experimental group of piglets after weaning showed a decrease in ASAT activity at 30 days of age - by $22.7 \%$, at 35 days of age - by $25 \%$ compared with the control group.

The most informative indicator of amino acid metabolism is the de Ritis coefficient (ratio of aspartate aminotransferase to alanine aminotransferase). The magnitude of this coefficient indicates the integrity of liver tissue cells, heart, skeletal muscles, and other organ tissues.

It was found out that in piglets of the control group the coefficient of de Ritis for the 30th day of life was 1.16, while in the experimental group -1.13 . On the 35 th day of the experiment, this indicator was higher in the experimental group of piglets fed the feed additive "Butaselmevit-plus" (Table 6). On the 40th day-old piglets, the ratio of de Ritis was 1.10 in the control group, 1.20 in the experimental group.

Table 6

De Ritis coefficient factor in serum of piglets for action of feed additive "Butaselmevit-plus" $(\mathrm{M} \pm \mathrm{m}, \mathrm{n}=5)$

\begin{tabular}{ccc}
\hline The day of & \multicolumn{2}{c}{ Groups of piglets } \\
\cline { 2 - 3 } life & control & experimental \\
\hline $20^{\text {th }}$ day & 1.19 & 1.20 \\
$25^{\text {th }}$ day & 1.12 & 1.18 \\
$30^{\text {th }}$ day & 1.16 & 1.13 \\
$35^{\text {th }}$ day & 1.14 & 1.29 \\
$40^{\text {th }}$ day & 1.10 & 1.20 \\
\hline
\end{tabular}

Notes: the degree of probability compared to the control group data: $*-\mathrm{P}<0.05 ; * *-\mathrm{P}<0.01 ; * * *-\mathrm{P}<0.001$

Increasing the activity of aminotransferases in the serum of piglets of the control group after weaning is associated with increased formation of reactive oxygen species in the organism, caused by a lack of vitamin E. Increased activity of alanine aminotransferase in the blood of piglets of the control group after weaning indicates increased alanine catabolism. While increased activity of aspartate aminotransferase activity is due to L-glutamate and oxaloacetate, which are formed by the transfer of amino groups from aspartic acid to $\alpha$-ketoglutaric acid in the presence of pyridoxal phosphate. Increasing the activity of aminotransferases in the serum of piglets after weaning from sows reflects the non-specific response of the organism to the action of stress factors and indicates the increased release of enzymes into the extracellular space.

When feeding piglets with feed additive "Butaselmevitplus" in their serum, a decrease in aminotransferases to the original values was established. The decrease in the activity of these enzymes in the serum of piglets after weaning to values, recorded in the period before weaning reflects their involvement in ensuring the supply of substrates in the tricarboxylic acid cycle, and ALAT indicates the efficiency of the feed additive "Butaselmevit-plus" for maintaining the homeostatic level of the glucose-alanine cycle. 
The decrease in the activity of aminotransferases in the blood of piglets of the experimental group, indicates that the components of the feed additive counteract the effects of stress, and also help to maintain the integrity of cell membranes specific to these organ enzymes, which prevents them from leaving the cells.

\section{Conclusions}

Weaning of piglets from sows at 28 days of age leads to a slight level decrease in total protein and increased activity of aminotransferases. Increasing the activity of ALAT and ASAT in the serum of piglets after weaning from sows reflects a non-specific reaction of the organism to the action of stress factors and indicates the increased release of enzymes into the extracellular space. Feeding piglets with feed additives "Butaselmevit-plus" promotes to enhance the protein synthesis function of the liver and reduce the activity of aminotransferases. The decrease in the activity of aminotransferases in the blood of piglets of the experimental group indicates that the components of the feed additive counteract the influence of stress, and also promote to maintain the integrity of cell membranes specific to these organ enzymes, which prevents them from leaving the cells.

\section{References}

Ahmad, M. K., Amani, S., \& Mahmood, R. (2011). Potassium bromate causes cell lysis and induces oxidative stress in humanerythrocytes. Environmental Toxicology, 29(2), 138-145. doi: 10.1002/tox.20780.

Chala, I. V., \& Rusak, V. S. (2016). Redox-potential and the state of peroxide oxidation of blood lipids in cows kept under ecologically unfavorable conditions. Scientific Messenger LNUVMBT named after S.Z. Gzhytskyj, 18, 2(66), 197-201. doi: $10.15421 /$ nvlvet6640.

Cherkashina, D. V., \& Petrenko, A. Y. (2006). Hepatoprotective effect of fetal tissue cytosol and its thermostable fraction in rats with carbon tetrachloride-induced hepatitis. B. Exp. Biol. Med., 141(4), 544-547. doi: 10.1007/s10517-006-0216-y.

Gutyj, B., Martyshchuk, T., Bushueva, I., Semeniv, B., Parchenko, V., Kaplaushenko, A., Magrelo, N., Hirkovyy, A., Musiy, L., \& Murska, S. (2017). Morphological and biochemical indicators of blood of rats poisoned by carbon tetrachloride and subject to action of liposomal preparation. Regulatory Mechanisms in Biosystems, 8(2), 304-309. doi: 10.15421/021748.

Gutyj, B., Stybel, V., Hariv, I., Maksymovych, I., Buczek, K., Staniec, M., Milczak, A., Bushueva, I., Kulish, S., Shcherbyna, R., \& Samura, T. (2019). Influence Of Amprolinsile And Brovitacoccid On The Protein Synthesizing Function Of The Liver And Enzyme Activity In Turkey Blood Serum During Eimeria Invasion. Research Journal of Pharmaceutical, Biological and Chemical Sciences, 10(2), 723-729. https://www.rjpbcs.com/ pdf/2019 10(2)/[99].pdf.

Khariv, I., Gutyj, B., Hunchak, V., Slobodyuk, N., Vynyarska, A., Sobolta, A., Todoriuk, V., \& Seniv, R. (2017). The influence of brovitatoxide in conjunction with milk thistle fruits on the immune system of turkeys for eimeriozic invasion. Scientific Messenger LNUVMBT named after S.Z. Gzhytskyj, 19(73), 163-168. doi: 10.15421/nvlvet7334.

Khariv, M., Gutyj, B., Butsyak, V., \& Khariv, I. (2016). Hematological indices of rat organisms under conditions of oxidative stress and liposomal preparation action. Biological Bulletin of Bogdan Chmelnitskiy Melitopol State Pedagogical University, 6(1), 276-289. doi: 10.15421/201615.

Khariv, M., Gutyj, B., Ohorodnyk, N., Vishchur, O., Khariv, I., Solovodzinska, I., Mudrak, D., Grymak, C., \& Bodnar, P. (2017). Activity of the T- and B-system of the cell immunity of animals under conditions of oxidation stress and effects of the liposomal drug. Ukrainian Journal of Ecology, 7(4), 536-541. doi: 10.15421/2017_157.

Kotsumbas, H. I., \& Hryniv, M. I. (2016). The influence of feed additives on productivity hematological and immunological parameters of the broiler chicks blood. Scientific Messenger LNUVMBT named after S.Z. Gzhytskyj, 18, 3(70), 157-160. doi: $10.15421 /$ nvlvet7037.

Lavryshyn, Y. Y., Varkholyak, I. S., Martyschuk, T. V., Guta, Z. A., Ivankiv, L. B., Paladischuk, O. R., Murska, S. D., Gutyj, B. V., \& Gufriy, D. F. (2016). The biological significance of the antioxidant defense system of animals body. Scientific Messenger LNUVMBT named after S.Z. Gzhytskyj, 18, 2(66), 100111. doi: $10.15421 /$ nvlvet6622.

Martyshuk, T. V., Gutyj, B. V., \& Vishchur, O. I. (2016). Level of lipid peroxidation products in the blood of rats under the influence of oxidative stress and under the action of liposomal preparation of "Butaselmevit". Biological Bulletin of Bogdan Chmelnitskiy Melitopol State Pedagogical University, 6(2), 22-27. doi: 10.15421/201631.

Petrukh, I. M., Simonov, M. R., \& Vlizlo, V. V. (2015). Mineralnyi homeostaz u koriv, khvorykh na ketoz, za likuvanni preparatom "Remivital". Naukovyi visnyk LNU veterynarnoi medytsyny ta biotekhnolohii. Seriia: Veterynarni nauky, 17(2), 183-188. https://nvlvet.com.ua/index.php/journal/article/view/486 (in Ukrainian)

Saba, A. B., Oyagbemi, A. A., \& Azeez, O. I. (2010). Amelioration of carbon tetrachloride-induced hepatotoxicity and haemotoxicity by aqueous leaf extract of Cnidoscolus aconitifolius in rats.

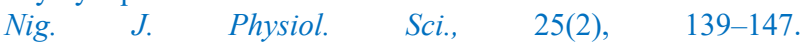
https://www.ncbi.nlm.nih.gov/pubmed/22314953.

Skry`pny`k, I. M. (2007). Gepatoprotetorni zasoby` v suchasnij gepatologiyi. Consilium Medicumllkraina, 1(5), 11-15 (in Ukrainian).

Sobolev, A., Gutyj, B., Grynevych, N., Bilkevych, V., \& Mashkin, Y. (2017). Enrichment of meat products with selenium by its introduction to mixed feed compounds for birds. Regulatory Mechanisms in Biosystems, 8(3), 417-422. doi: 10.15421/021764.

Vlizlo, V. V., Fedoruk, R. S., \& Raty`ch, I. B. (2012). Laboratorni metody' doslidzhen' u biologiyi, tvary`nny'cztvi ta vetery`narnij medy`cy`ni: dovidny`k. L'viv: Spolom (in Ukrainian).

Zhukova, I. O., Svitlychna-Kulak, Yu. S., \& Longus, N. I. (2016). Correction of stateof antioxidant protection in dogs when poisoned byneoverm. Scientific Messenger LNUVMBT named after S.Z. Gzhytskyj, 18, 3(70), 95-99. doi: 10.15421/nvlvet7022. 